Cernea, M. Micheal, 1985. Putting People First, Washington DC: World Bank, 1985.

Chhetry, R.B. and T.R. Pandey, 1992, User Group Forestry in the Farwestern Region of Nepal. Kathmandu ICIMOD.

Dahal, D.R. 1994. A Review of Forest Users Groups: Case studies from Eastern Nepal. International Centre for Integrated mountain Development, Kathmandu, Nepal.

Fricke, Thomas E., 1993. Himalayan Households: Tamang Demograhpy and Domestic Processes, Book Faith India, Delhi.

Gilmour D.A. and Fisher, R.J. 1991. Villagers, Forest and Foresters: The Philosophy, Process and Practice of Community Forest in Nepal. Kathmandu, Sahayogi press.

HMG/Nepal, 1989. Economic Survey, Ministry of Finance, Kathmandu

ICINOD, 1986. Decentralized Energy Planning Management in the Hindukush Himalayas, ICIMOD, Kathmandu

Ministry of Finance HMG/Nepal, 2001. Economic Survey, Kathmandu.

Noronha, Raynmond and John S. Spears, 1985. "Sociological Variable in Forestry Project" In Michael M. Cernea (ed.) Putting People First Washington DC, World Bank.

Pokharel, Binod, 1991. Forest Consumption Pattern in Dhankuta M.A. Dissertation in Anthropology (Unpublished) Submitted to the Central Department of Sociology/Anthropology, T.U. Kirtipur.

Pokharel, Durga and Anthony B. J. willet, 1996. History of an Indigenous Community Management Organization in Nepal. Indigenous Organization and Development (ed.) peter Blunt and D Michael Warren, Intermediate Technology Publications Ltd. London, UK.

Saussan, J., B.K. Shrestha and L. P. Uprety 1995. The Social Dynamics of Deforestation: A Case Study from Nepal. Published in the UK and Europe by the Parthenon Publishing Group Limited Casterton Hall, carnforth, England.

Stevens, F. Stanley, 1993. Claiming the High Ground; Sherpas Subsistence and Environmental Change in the Highland Himalayan, Motilal Banarsidass Publishers Private Limited, Delhi, VDC, Record of Belahara, 2001.

Wallance, Michael, B. 1988. Research Report Series, WINROCK, Kathmandu

Wood and Energy Commission, 1987. Fuelwood Supply in the District of Nepal

\section{STRATEGIES AND PRACTICES OF ADVOCACY: GENDER ADVOCACY AGAINST TRAFFICKING IN WOMEN IN NEPAL *}

\author{
Meena Poude \\ Youba R. Luintel
}

\subsection{Introduction}

Advocacy is an organised and sustained campaign to get the interest of the marginalised people represented and addressed in public policy, attitudes or practices. It is a deliberate, systematic and organised way of influencing effective implementation of existing policy, change it or formulate alternative policies in favour of targeted area/group/issue. The goal of advocacy is to challenge the powerful in favour of the deprived and disadvantaged ones, such as Dalit, ethnic minorities, landless, women, children and older people.

While there has been a growing body of literature on empirical cases of trafficking in women, movement against it has been rarely documented and discussed. This paper attempts to critically analyse gender advocacy from the light of Social Relations Approach (SRA), especially from the framework of Institutional Analysis (IA). We argue that while trafficking in women has become a lucrative business for profit-making, a critical analysis of the institutions involved in it and a concerted

\footnotetext{
Ms. Poudel is a feminist activist and development anthropologist currently working as Program Representative for Oxfam GB in Nepal. Mr. Luintel is a sociologist specialising on gender issues and teaches gender course at Central Department of Sociology/Anthropology, Tribhuvan University
} 
effort against them would definitely yield some results. Referring to the case of anti-trafficking campaign in Nepal, we attempt to introduce the notion of advocacy in general and gender advocacy in particular.

\subsection{The Notion of Advocacy}

The concept of advocacy entered into the NGO sector as a strategy and a tool to change policies and practices of institutions and to contribute for lasting social change. Around 1980, a growing number of NGOs in the Southern underdeveloped and Northern developed countries have intensified their advocacy work in local, national, regional and global levels to counter the constraints placed on their development efforts by national, regional and global powers the market forces and the state mechanism. Particularly in the issues of gender, NGOs and women's movements in national and global levels have intensified their advocacy after the Third World Conference on Women in 1985.

Advocacy is the speaking up about a problem or an issue in the relevant political arena in order to improve the situation for those affected by that particular problem. It is an essential part of the most of NGOs and human rights groups who aim to bring about vital social changes. It is a process of widening support through networking and alliance building in order to bring changes in the policies. An advocacy campaign is a set of targeted actions in support of particular cause. A base of any advocacy is essentially a common issue.

In advocacy, NGOs play critical role to change policies and practices at different levels. NGOs claim themselves as ambassador of the poor, socially excluded, and discriminated due to their specific class, gender, age and ethnic identities. Political dimension of poverty, powerlessness and suffering is the major area of concern of any advocacy.

\section{$2.1 \quad$ Elements of Advocacy}

There should be a clear understanding of the political culture and effective ways of bringing about policy changes in that cultural context. The agenda of the changes should reflect the perspectives of the affected communities. Lobbying initiatives for policy changes should be firmly grounded in community based campaigns affected by the issue. Leadership (of an organisation, a group or an individual) with clear political analysis based on specific cultural context is very important to make an advocacy successful. The way activities are

\section{Box 1: Elements of advocacy}

- Dynamic leadership

- Wider public support

- Effective communication

- Collaborative partnership organised (or strategies are determined) at various levels and stages is also very important to make an advocacy effective. However, activities may change during the course of implementation. Therefore, it depends entirely up on the given context including political and cultural sub-contexts. The advocacy group(s) should aim at building strong and enthusiastic public support that could influence policy-makers at various levels. There should be an effective communication system with different sectors. The organisation or the group that aims to advocate for social change through gender justice should set up (a) concrete objectives, (b) attainable targets, and (c) clear strategies. Most importantly, groups, organisations and individuals need to have equal partners with whom they can share views, values and beliefs.

\subsection{Steps of Advocacy}

On the whole there are four main steps in any advocacy campaign. They are planning (issues identification; research and information-base; setting objectives and goals of the campaign; and, designing strategies); preparing resources (lobbying, networking and alliance building, and; resources generation); launching the campaign, and finally; monitoring and evaluation.

Identify problem(s) : First step in any advocacy is to identify and choose the main problem to advocate for or against it. An organisation, a group or an individual who wishes to advocate for gender justice in particular problem should consider 
some key questions, such as: Is the problem really related to the women's rights issue? Does the problem educate a wider community and help them bring in support? Will the problem contribute to strengthen gender justice? Will this help expand the scope of state responsibilities? To what extent does the problem address women's practical gender needs (PGNs) and strategic gender interests (SGIs)?

Do research and identify critical issues: Next step, for any advocacy groups or individuals, is to identify key and critical issues within the problem. Some pertinent questions could be: What is the nature of injustice? How can the injustice be proved? Are there documented cases against it? Who are the violators or perpetrators? Which social institutions (the family, community, market or state) are found to be directly (or indirectly) responsible for that particular problem? Which legal tools help confirm the injustice or violation? Which international human rights standards has the state ratified? Is there any possibility of linking the issue with those human rights standards? What is the possibility of satisfactory solutions to be expected at local, national, regional and international levels? Do the public understand the issue? Is there any possibility of mobilising wider public to generate awareness and gain support?

Set objectives and demands: This step is very critical for the ones who wish to contribute in the process of advocacy. It basically deals with what advocacy organisations or individuals want to achieve. Some key questions to be addressed are: What is the possibility of success of the advocacy issue? Which aspect of advocacy issue needs to be focussed? Is it possible to monitor some mid-term or final objectives? Does the issue have some positive impact on gender relations with respect to class, caste and religion? These are some examples to set out clear advocacy objective(s).

Design strategies: In order to achieve the set objectives, the advocacy groups or networks should set their strategies very clearly. Strategies should be devised in such a way that it could constructively influence the existing policies and practices at its different levels. The larger political context of the issue should also be considered while setting the strategies. The strategies should be such that the advocacy should help enlarge its allies, gain wider support and single out the opponents. There are many ways to formulate strategies which, however, depend heavily on local contexts. Ethnicity, class and religion are some major factors that shape the local context of advocacy in relation to gender. Sociological literature suggests that women from ethnic minority group, non-Hindu background and economically lower strata enjoy relative autonomy and freedom than women from caste groups, middle or high class strata and Hindu background. In such a context, gender advocacy strategies should address these realities first. On the whole, gender advocacy should constantly challenge the patriarchal ideologies and practices in every stage.

Networking and alliance building: Advocacy is a complex task with full of challenges, political, social and ideological. It is much more difficult in societies like Nepal that are predominantly feudal and patriarchal. The advocacy groups, therefore, should enlarge their partnership and networks to gain wider support from the public. If necessary, the campaigners should build their own alliance or mobilise the existing ones to make the issue effective and vibrant. Since

\section{Box 2: Forms of Alliance Building}

- Lobbying is one of the strategies to strengthen advocacy process, which aims to bring policy and practice change in particular, issue.

- Networking refers to both formal and informal communication between individuals and agencies working on similar issue. Network is usually developed and maintained by keeping regular contact with the agencies or people who are interested on issues agreed.

- Coalition refers to a mechanism to build a network between existing agencies where the organisations/ agencies become members either temporally or for a longer period. Though the coalition works on a common concern, each organisation retains its own background, thus giving space for differences and open discussion. 
advocacy is more a collaborative action, single and isolated efforts are highly likely to be less effective. Some relevant questions to be addressed are: Who are the potential allies and opponents for gender justice? Where are they located, in which level (vertically and horizontally)? Who are the main targets and where are they located? What can be the role of media to sensitise the public? How can the opponents be neutralized?

Generate resources: A reserve of flexible resources (human, material and financial) is very essential for a successful advocacy campaign. First, mature, articulate and politically clear human resource is crucial to carry out the critical analysis of the agenda. We need to analyse the political economy of the agenda critically and identify potential cultural barriers (implicit or explicit) that might impede women's rights issues from entering into public discourse. Second, a stock of literature and publication with clear political position is essential to further advocacy campaign effectively. Also we need other tools and equipment to sustain the campaign. Third, availability of a reserve of loose and flexible financial resources is very crucial. In course of advocacy campaign, often we need to change our strategy and alliance frequently to respond to the changing circumstance(s). There may be many hurdles to work with the project-based and pre-allocated budget. Therefore, availability of flexible funding that could be utilized beyond project boundary, on quick and circumstance-driven decisions, is very much essential.

Action and implementation: If there are clear objectives, strategies and monitoring mechanism, we can start implementing the action plan. Action plan should have clear linkages, vertically and horizontally, to bring wider impact on policies and attitudes. Action plan needs to be flexible, since we cannot work with same plan in all circumstances. It should be very clear who is in charge of implementing particular part of the action plan, ensuring that his/her political vision does not contradict with the set objectives and strategies. There should not be any "gap of understanding" between those who designed the campaign and those who implement it. Finally, field reality (social structure, cultural differences and religious beliefs of the stakeholders, their ethnic/caste and gender dynamics, etc.) should be given utmost consideration before actually initiating the campaign.

Monitoring and evaluation: While evaluating advocacy, we usually focus on short-term outcomes and longterm impact against the stated objectives. Some key questions are: What is the state of progress on objectives and goals? To what extent are the strategies effective to achieve those objectives? Are the plans working well? Are they practical in the given context? What has been the final outcome and impact with respect to gender relations between women and men (with respect to PGNs and SGIs)? To what extent have social institutions become sensitive in protecting the rights of women along with their male counterparts? Has the state formulated any gender redistributive policies? And finally, was the issue chosen for gender advocacy really suitable and relevant?

There should be a clear, locally adaptable, and culturally and politically sensitive mechanism to monitor gender advocacy

\footnotetext{
There are many cases of gender issues being evaporated. For example, the National Network against Girls Trafficking (NNAGT), one of two leading advocacy groups in Nepal that deals with the issues of women in trafficking appears completely different in operational level than its claim of following human rights approach. NNAGT is clearly following welfare approach. The Alliance against Trafficking in Women and Children (AATWIN), another advocacy group, has the problem of diversity. Many of its member organizations deal with the issue but on their own way. Thus, the challenge to both NNAGT and AATWIN is translating the originally envisaged vision, strategy and programs in the practice. Even some of the United Nations agencies in Nepal do not precisely follow United Nations human rights principles while implementing their programs. The UN Task Force on Trafficking and its Joint Initiatives on Trafficking (JIT) project, for example, have considerable deviation from UN's internationally recognized human rights standards to deal with the trafficked persons.
} 
campaign. Since gender advocacy mostly includes qualitative issues, such as change in attitude, behaviour, policy and practice, etc. quantitative indicators often do not reflect the success, effect and magnitude of the outcomes. Selection of proper indicators is, therefore, very crucial in gender advocacy. Developing qualitative indicator(s) to monitor change in attitude, practice and belief is more complicated than monitoring policy change. Policy change as a matter of fact is visible (therefore, less challenging) than attitudinal and behavioural changes. Change in attitude and behaviour is not only a time-consuming and slow process but also invisible.

Due to the temptation of finding "visible outcomes," monitoring and evaluation of (gender) advocacy might pose two dangers. First, there is danger of moving beyond the set objectives and agreed principles of the campaign. Second, there is equally high possibility of arriving at spurious conclusion that the campaign could not generate any success outcomes (due largely to their invisibility).

\subsection{Gender Advocacy}

Gender concerns reflect a shift of focus in development policy and programme from the welfare to the equity, the efficiency and finally the empowerment approach. Such approaches are also seen to coexist, either as single policies of particular state institutions or mixed and matched within an organisation. But there is often hope for coherence.

Most importantly, the distinction made is between two policy perspectives: WID (women in development) and GAD (gender and development). The WID approach aims to include women in development programme in order to make them efficient, while GAD aims to address inequalities in women's and men's social roles in relation to development. As one of the recent development debates all over the world the latter was largely shaped in course of women's movements and demands for the inclusion of gender issues in the development process.

\subsection{Framework of Analysis for Gender Advocacy}

Advocacy as a process encompasses many activities. For gender advocacy, for example, some or all of the following activities or a combination (of few) could be devised. Possible activities include, among others:

(a) identification of a particular issue,

(b) access to and collection of relevant information,

(c) media campaign,

(d) awareness campaign,

(e) mass mobilisation and/or demonstration,

(f) lobbying, coalition building or networking,

(g) civil disobedience,

(h) litigation,

(i) influencing policy decision and discussion at the locallevel governance units, and

(j) influencing parliamentary discussions.

Currently there are more than half a dozen of internationally recognised frameworks to analyse gender relations and develop gender advocacy plan. Those are Social Relations Approach (SRA), Gender Analytical Framework (GAM), Women's Empowerment Framework (WEF), Moser Framework, Harvard Analytical Framework and Capacities and Vulnerabilities Analytical Framework (CVA), etc. Experience has shown that each of the frameworks needs specification and local adaptation. Using any framework must not ignore cultural differences. Difficulties often arise while translating their key terms used. It is so while linking the local context and local case (which reflect the reality of individual location) with the globally applicable framework. It's a challenge of micro-macro linkages. 
Here, we will try to describe SRA as an example to show how this framework helps us in gender advocacy campaign in specific circumstance. Naila Kabeer, at the Institute of Development Studies, University of Sussex, developed SRA and has widely been used by NGOs, advocacy groups and donor communities. SRA analyses gender relations in relation to social institutions involved and perceives gender relations as part or reflection of social relations. In this sense, SRA is a tool to analyse gender inequality in the distribution of resources, responsibilities and power. Theoretically, SRA is more inclined towards socialist feminist school of thought. The point of departure of SRA is its perception that the ultimate goal of development should be human well-being. The concepts of social relations and institutional analysis are centrally located in the framework of SRA. SRA has two major uses so far as gender is concerned. First, it is a method of analysing existing gender inequalities with respect to distribution of resources, responsibilities and power. Second, SRA helps design gender policies, advocacy plan and programmes to enable women to be the active agent of their own development and justice.

For SRA, development is all about increasing human well-being, which can be seen as concerned to the survival, security and autonomy of human being. Social security and autonomy are closely linked to gender, ethnic, caste and racial dimensions of discrimination. The concept of social relation is central to the framework of SRA. Social relations are different structural relationships that create and reproduce systemic differences in the positioning of different groups of people. Gender relations refer specifically to those dimensions of social relations that create and reproduce differences in the positioning of men and women.

In a patriarchal society like ours, gender relations accord men than women a better privilege and opportunity to social roles, material resources and political power. Social relations can also be seen as resources that groups and individuals have, and these social resources often play a crucial role in the survival of people living in poverty, distress and powerlessness.
Below, an attempt has been made to apply one important element of SRA, the institutional analysis, on gender advocacy in Nepal, referring to trafficking in women as a case.

\subsection{Institutional Analysis of Gender Advocacy}

An institution refers to a framework of rules for achieving certain social, political and economic goals (Kabeer, 1996). Institutions reinforce and reproduce patterns of social relations and thereby create and perpetuate social differences and social inequalities. Organisations, in the other hand, are the specific structural forms that institutions take. An institution operates with official ideologies shaped by its set goals and procedures.

Under the framework of Institutional Analysis (IA), gender advocacy requires analysing how these institutions and organisations actually create and reproduce gender inequalities in society. For understanding an institution it is necessary to analyse the rules, resources, practices, people and power/hierarchies of command and control in order to uncover how gender is constituted as relations of inequality. IA as a framework of analysis draws attention to the way gender is constructed as relations of inequality reinforced by the rules and practices of different institutions, both separately and through their interaction. IA identifies four institutional locations for the analysis: the state, the market, the community and the household. An IA makes it clear how gender is constructed in different levels and terrain of social relations.

While applying IA in the case of trafficking in women in Nepal, first we have to set clear and precise objective(s). One possible objective could be to identify social institutions and locate their role in the criminal business of trafficking. If we really identify all the institutions involved and explore their existing or potential roles, it would help us in strategizing ourselves to single out the enemies against whom we have to fight, and allies with whom we could collaborate in achieving the common goals. Table 1 shows tiers of institutions involved 
and their organizational and structural location in the criminal business of trafficking.

Table 1: Institutions in different domains of women and men relationships

\begin{tabular}{|c|c|c|}
\hline Level & Institutions & Motives \\
\hline State & $\begin{array}{l}\text { Legal bodies, administrative } \\
\text { organisations, ministries, village and } \\
\text { district development committees and } \\
\text { departments. }\end{array}$ & $\begin{array}{l}\text { National } \\
\text { welfare }\end{array}$ \\
\hline Market & $\begin{array}{l}\text { Recruiting agencies, employment } \\
\text { generating agencies, media, factories, } \\
\text { industries, distribution network, e.g. } \\
\text { brothels. }\end{array}$ & $\begin{array}{l}\text { Profit } \\
\text { maximisation }\end{array}$ \\
\hline Community & $\begin{array}{l}\text { Villages, communities, social norms, } \\
\text { informal networks, political parties, } \\
\text { religious institutions, NGOs/CBOs, } \\
\text { patron-client relationship. }\end{array}$ & $\begin{array}{l}\text { Service and } \\
\text { moral } \\
\text { economy }\end{array}$ \\
\hline Household & Families, lineage groups, etc. & $\begin{array}{l}\text { Altruism } \\
\text { and co- } \\
\text { operation }\end{array}$ \\
\hline
\end{tabular}

The state is supposed to take the responsibility for those who are at risk of trafficking. Usually, state has holds a conservative attitude while dealing with such issues. Consequently it is almost difficult to get flavour of human perspective towards women in terms of recognising their autonomy and independence. An anti-trafficking law in Nepal, for example, is much more victim-centred thus ignores crime part where mostly men are located. Before 1990, trafficking was not even recognised as a problem by the state. Now, trafficking has been accepted as a problem but still as one of women's problems. Gender advocacy groups had very hard time to convince the government that it is not a problem of women only, but a national problem.
Although

Nepal has signed

almost all

international

instruments,

including

CEDAW, Beijing

Platform for

Action, and

trafficking

convention and

protocol, still the

state seems always

reluctant so far as

their

implementation is concerned. Legal institutions such as Ministry of Law, Laws Reform Commission, Courts and Bar Associations are overtly patriarchal and conservative, heavily dominated by middle class men from higher castes. Law enforcing bodies such as Nepal Police, Armed Police and Royal Nepal Army too are not exception to this. It is very hard and embarrassing for a trafficked woman (and her family) to go through the official legal process and get justice. One typical example is the parliament and the bills related to trafficking control and violence against women, and, of course, the eleventh amendment of civil code popularly known as women's rights bill.

The anti-trafficking bill has been overtly victim-centred and does not even touch upon the criminal part of trafficking. ${ }^{2}$

2 Similarly, the bill on violence against women does not reflect Nepal's international commitments, such as Beijing Platform for Action, and UN Human Rights principles, although Nepal has ratified both. Regarding women's property rights bill, the government passed it from the parliament, but again without substantial improvements in the existing legal discrimination. Now gender activists have clear tow positions in it: (a) the welfare- 
The National Plan of Action against trafficking in women and children for commercial sexual exploitation, for example, is indicative itself to see how far is it victim-centered. Of the six main areas identified, none of them attempts towards controlling the perpetrators effectively. The six working areas identified are (1) policy, research and institutional development; (2) legislation and enforcement; (3) awareness creation, advocacy, networking and social mobilization; (4) health and education; (5) income and employment generation, and; (6) rescue and reintegration (see Ministry of Women, Children and Social Welfare, 2000).

The same applies to the SAARC Convention to combat trafficking. Since 1996, gender activists of the SAARC countries were asking collectively that trafficking issue be accepted officially into the SAARC process. Although the Kathmandu (Eleventh) Summit (2002) formally approved the convention ${ }^{3}$, it did not include activists' demand that trafficking issue be looked from rights-based approach.

After the escalation of liberal economic policies in Nepal, market has become stronger than the state mechanism in relation to trafficking. Licensing of the recruiting agencies (that does not include human cost), migration policies (which are gender-blind) and the media (which have capitalistic orientation) are some examples of how market as a social institution plays crucial role in trafficking.

centred activists support the bill, (b) while those following the human rights principles have many reservations and disagreements on what has been passed. The implication is that the state has failed to prosecute the perpetrators and thereby to protect the rights of the affected women and their families.

3 While the Male (Ninth) Summit (1997) had accepted the issue for its consideration, it was the Colombo (Tenth) Summit (1998) that endorsed the draft for final consideration.
On the whole, rather than protecting women's rights and allowing them to exercise their freedom, market forces promote women's trafficking for their economic benefits. Before the government started issuing

licence to

recruitment agencies, trafficking used to happen with few women and was confined within South Asia only. When agencies were allowed to operate their business, trafficking started in a mass scale and the market extended beyond Asia. For

\section{Box 5: Case Study}

Ms. Radha (a trafficked survivor, nicknamed) was kept in custody for about two years (1988-1990) in Kathmandu. When she got HIV positive, the brothels in India (where she was kept as captive) first ousted her. She was also not allowed to stay in her society and family back in Nepal. Eventually, she was taken to custody. After the restoration of democracy in 1990, the interim government released her from the custody and offered a lowly paid job under the Ministry of Health. However, after one year she was disposed from the service on the charge of HIV positive (for which cause she was given employment earlier). An NGO working for the cause of women at risk then picked up her and offered a job at its office as a token of sympathy. She served there for two years (1992 1994). Due to an increasing gap between employer's normal job expectation and her weakening health, she was eventually forced to resign. She is still alive and maintaining her life on her own within the triangle of social rejection, state repression and civil society disposal. example, groups of brokers of recruitment agencies visit districts these days and attempt to lure as much women as possible for unknown jobs. ${ }^{4}$

For example, couple of months ago one such group including some local persons visited Sindhupalchowk and Rupandehi districts in a similar purpose and succeeded to persuade some 29 girls and women. These brokers neither had any official document nor had any reliable paper of jobs offer. Of the total 29 women targeted, 18 were Tamang and the rest Tharu by their ethnic belonging. Fortunately, some local NGOs and the concerned families found them doubtful and managed to save the girls and women from being trafficked. 
Before 1995, Nepali media too tended to expose trafficked women negatively which used to disclose the identity of the victims and heightened their social stigma. With the continued advocacy of feminist groups and NGOs alike, however, the role of Nepali media seems to have been improved recently. Still, there is a long way to go to make the market sensitive to gender issues in relation to trafficking.

Community and civil society too are making trafficking issue much more complex due mainly to two reasons. First, the service delivery mechanism of the society is much more inclined to welfare approach. Second, the tendency of NGOs preferring to work in certain territory (only) has created problems of coordination and sharing. Most of the NGOs are covertly patriarchal. Furthermore, they are politically less matured also, thus lack conceptual clarity on the issue.

From the grassroots to the international level, gender advocacy against trafficking in women has revealed two clear positions, viz., (a) the conventional and orthodox "welfare approach," and (b) the liberal and empowerment-centred "rightsbased approach." The followers of the welfare approach hold moralistic position and adopt repressive strategies. For instance, it attempts to restrict women's mobility in public places and gives stress on rehabilitation of those women who are already victims. Unlike it, the proponents of human rights approach advocate for autonomy and fundamental rights of women while addressing the issue of trafficking. They attempt to incorporate empowerment strategies as an integral part of their campaign.

This is how both NGOs and advocacy groups are divided in two clear fronts for anti-trafficking campaign. Due to the division of civil society like this, there has been a lack of consolidated and concerted effort. Directly or indirectly, it has allowed the market and the state mechanisms not assuming their responsibilities effectively.

Households are the main location of care and affection of family members. But patriarchal power relations within the family and the discriminatory social norms and morals towards women have added vulnerability to women. In relation to trafficking, while market creates a negative image of women, the community formulates patriarchal values, and the family rejects a woman once she is trafficked. In Nepalese context, it is almost impossible for a woman to be normally accepted within her family once she is trafficked. There are many cases of women suffering repeatedly because of the family rejecting them. In some few cases where the family is willing to accept her, the wider community (primarily, either kin and/or the neighbourhood groups) discourages and ridicules on the family itself.

\subsection{Conclusion}

Each individual, both male and female, lives amidst the web of social relationships. An analysis of social relations, therefore, occupies a central position in Social Relations Approach (SRA), Recognising gender as a form of social relations, the SRA focuses on connectedness and embeddedness of relationship between women and men. Gender relations are considered as relations of inequality due largely to the discriminatory rules and practices of different institutions. In such a systemic situation gender relations are connected to other systems in society of which power is one important concept. Power has been at the centre of SRA approach as well, also because power needs constant debate and continuous challenge for making the society equity-based.

Advocacy is a campaign launched on the part of civil society actors that aims at influencing public decision-making for the benefit of relatively marginalized section of society. Gender advocacy in particular is also the same process with primary attention towards making relations between women and men more equity-based. Since women are often in disadvantaged position, gender advocacy focuses on empowering them vis-à-vis their male counterparts. Building women's (or mixed) alliances and networking is one of the main activities of feminist advocacy campaign.

As a country of periphery, Nepalese women and girls are trafficked to the countries of semi-periphery or core status. With the growing incidence of trade on human body, especially that of trafficking in women, a vibrant advocacy campaign has also emerged in Nepal very recently. While Indian brothels have been 
the main destination, recently trafficking business has also extended its hands up to gulf and some East Asian countries. This paper shows that gender advocacy like any other advocacy campaigns is a systematic body of activities, each linked to other logically and aimed at achieving the set goals or objectives. It shows that identifying the actors involved, their location and linkage in the tier of social institutions and identification of potential enemies and allies would greatly help achieve the target. In this process, IA could be one important tool that gender advocates could apply.

Both the authors would like to acknowledge frequent consultation of Fenella Porter, Ines Smyth and Caroline Sweetman (1999), Global Alliance against Trafficking in Women (1999), Jo Rowlands (1997), Ministry of Women and Social Welfare (1999 and 2000 BS), C. Moser (1993), N. Kabeer (1996), and Oxfam GB Nepal Program (2000).

\title{
REFERENCES
}

Global Alliance Against Trafficking in Women (1999) Human Rights in Practice: A Guidebook to Assist Trafficked Women and Children, Bangkok: GAATIW.

Kabeer, Naila (1996) Reversed Realities: Gender Hierarchies in Development Thought, New Delhi: Kali for Women.

Ministry of Women and Social Welfare (1999), Beijing Plus Five, Country Report, Kathmandu: HMG/N.

Ministry of Women, Children and Social Welfare (2000), Combat Against Trafficking in Women and Children for Commercial Sexual Exploitation: Policy, Action Plan and Institutional Mechanism, Kathmandu: HMG/N.

Moser, Caroline (1993), Gender Planning and Development: Theory, Practice and Training, New York: Routledge.

Oxfam GB Nepal Program (2000), "Trafficking in women in South Asia: An organised crime against women" (A study conducted and submitted to UN special rapportuer on violence against women).

Porter, Fenella, Ines Smyth and Caroline Sweetman (1999) Gender Works: Oxfam Experience in Policy and Practice, an Oxfam publication, Oxford.

Rowlands, J. (1997) Questioning Empowerment: Working with Women in Honduras, an Oxfam publication, Oxford.

\section{THE POSITION OF DALIT WOMEN IN CASTE SYSTEM}

\author{
Samira Luitel ${ }^{*}$
}

\section{Background}

Out of the 22 million population of the country it is estimated that the total population of Dalits is 20\% (CERID, 1997) of which female Dalits occupy half of that population. Except for a few, the total segment of this population leads a miserable life. Socially discarded for a long time, they are compelled to live a vulnerable life be it economic, education, health and all the other areas that fall under basic needs. The word Dalit itself connotes the lowest strata of the society in all the aspects, a term which is condemnable itself. One has to go back to its history to understand the situation of the Dalits. Based on the Hindu caste system the total social system is divided into hierarchies since long, where people are divided into various caste and ethnic groups. In this background the position of Dalit women is one of the lowest from all these aspects.

The major caste groups as stated in the religion are four Brahmin, Kshatriya, Vaisya, and Sudra. Sudra which was placed at the bottom of the ladder in the caste hierarchies is termed as Dalit these days which is the untouchable groups in the society. Besides the caste groups, there are about 60 ethnic groups (CERID, 1997) in the country. No caste discrimination is found in the ethnic groups except in the Newars. Outlawed in the year 1963 itself, without no strong action against it, the practice of untouchability still exists in all parts of the country. As it has not

Dr. Samira Luitel is the Lecturer in Sociology at the Central Department of Sociology and Anthropology, Tribhuvan University, Kirtipur, Kathmandu. 